Jurnal Positif, Volume 3, No.2, 2017 : 106 - 112

\title{
SISTEM INFORMASI GEOGRAFIS SEBAGAI PENDUKUNG PENATAAN RUANG TERBUKA HIJAU KAWASAN PERKOTAAN (RTHKP) KOTA BANJARMASIN
}

\author{
Subandi ${ }^{1}$ \\ ${ }^{1}$ Teknik Informatika, Politeknik Negeri Banjarmasin \\ Email : subandi@poliban.ac.id
}

\begin{abstract}
Abstrak
Sistem informasi geografis atau singkatnya SIG merupakan suatu sistem yang berbasis komputer dan mampu menghasilkan informasi angka maupun peta aktual. SIG memiliki kemampuan memvisualisasikan suatu informasi yang berguna untuk merencanakan, mengelola serta memantau perkembangan suatu pekerjaan geografis.

SIG juga digunakan untuk mengumpulkan, menyimpan, menggabungkan, mengatur, mentransformasi, memanipulasi dan menganalisis data - data yang erat kaitannya dengan bidang spasial dan geoinformasi. Salah satu perangkat lunak yang banyak digunakan adalah MapInfo Professional yang mempunyai karakteristik yang menarik, mudah digunakan, User Friendly dan memiliki tampilan yang interaktif. MapInfo Professional telah terbukti menjadi tool yang powerfull dalam sistem informasi geografis.

Dengan teknologi Program Sistem Informasi Geografis Sebagai Pendukung Penataan Ruang Terbuka Hijau Kawasan Perkotaan (RTHKP) Kota Banjarmasin, bisa memberikan informasi lahan-lahan mana saja yang sesuai untuk RTHKP secara cepat, tepat dan sesuai dengan keadaan sesungguhnya dan juga sebagai sarana bantu dalam mengambil suatu keputusan dalam perencanaan dan penataan RTHKP kota Banjarmasin.
\end{abstract}

Kata kunci :Gis.RTKHP,kawasan hijau

\section{PENDAHULUAN.}

Latar Belakang

Kota Banjarmasin adalah salah satu kota sekaligus merupakan ibukota dari provinsi Kalimantan Selatan, Indonesia. Kota ini memiliki luas wilayah $72 \mathrm{~km}^{2}$ atau $0,019 \%$ dari luas wilayah Kalimantan Selatan. Kota Banjarmasin terletak pada $3^{\circ}, 15$ sampai $3^{\circ}, 22$ Lintang Selatan dan $114^{\circ}, 32$ Bujur Timur, ketinggian tanah berada pada $0,16 \mathrm{~m}$ di bawah permukaan laut dan hampir seluruh wilayah digenangi air pada saat pasang (www.wikipedia.org, 2009).

Ruang Terbuka Hijau (RTH) merupakan salah satu aspek penting dalam penataan kota, terutama yang didominasi oleh air seperti kota Banjarmasin. Penyediaan RTH itu diatur dalam Peraturan Menteri Dalam Negeri Nomor 1 Tahun 2007 tentang Penataan Ruang Terbuka Hijau Kawasan Perkotaan (Seperti pada Lampiran 1). RTH berfungsi sebagai pengamanan keberadaan kawasan lindung perkotaan, pengendali pencemaran dan kerusakan tanah, air dan udara, tempat perlindungan plasma nuftah dan keanekaragaman hayati, pengendali tata air dan sarana estetika kota. Jenis RTH kawasan perkotaan meliputi taman kota, taman wisata alam, taman rekreasi, taman lingkungan perumahan dan permukiman, taman lingkungan perkantoran dan gedung komersial, taman hutan raya, hutan kota, hutan lindung, bentang alam seperti gunung, bukit, lereng dan lembah, cagar alam dan lainnya. Luas ideal RTH kawasan perkotaan minimal 20 persen dari luas kawasan perkotaan.

Berdasarkan peraturan tersebut, maka kawasan kota Banjarmasin yang termasuk wilayah rawa pasang surut harus menempatkan RTH sebagai salah satu aspek penting dalam penataan kota. Hal itu bukan hanya menjadi tanggung jawab Pemko, tetapi juga masyarakat yang bertempat tinggal di kota. Selain dituntut kesadaran dalam penyediaan RTH di sekitar permukiman, juga diperlukan suatu aturan yang mengatur tentang RTH dalam pendirian bangunan. Aturan itu diimplementasikan dalam IMB (Izin Mendirikan Bangunan). Itu cara yang efektif bagi pemerintah dalam peningkatan keberadaan RTH di lingkungan pemukiman, sehingga pada saat masyarakat mendirikan 
bangunan, mereka diwajibkan menyisakan lahan untuk RTH. RTH di lingkungan permukiman juga memberikan aspek arsitektural dan artistik visual pada pemukiman tersebut. RTH secara umum bisa berfungsi sebagai pengontrol pemandangan, penghalang secara fisik, pengontrol iklim, pelindung dari erosi dan memberikan nilai estetika

\section{Perumusan Masalah}

Dari hasil survei, penulis dapat mengevaluasi sistem yang ada:

- Informasi yang di dapat masih kurang (misalnya: kurangnya data suatu jalan karena survei hanya dilakukan pada jalan-jalan besar saja, data RTHKP yang kurang lengkap karena tidak semua tempat RTHKP kami survei).

- Belum adanya pendataan RTHKP secara rinci.

- Belum adanya sistem yang memberikan informasi dan yang dapat digunakan dalam penataan RTHKP.

- Kebutuhan sistem yang kurang optimal baik secara fungsional maupun non fungsional.

Pemecahan Masalah

Adapun pemecahan masalah dari hasil evaluasi di atas, yaitu:

- Dari informasi yang terbatas, penulis mencoba menganalisis dan mengembangkan data-data apa saja yang diperlukan.

- Sebisa mungkin penulis mencoba melakukan pendataan RTHKP dengan mendatangi tempat lokasi RTHKP.

\section{TINJAUAN PUSTAKA}

SIG (Sistem Informasi Geografis) merupakan suatu alat yang digunakan untuk pemetaan dan analisa terhadap banyak aktifitas di atas permukaan bumi, SIG ini dibangun berdasarkan data statistik dan peta geografi yang mengarah pada spesifikasi lokasi dalam suatu ruang. Teknologi SIG ini menggabungkan antara operasi database, seperti table, query, dan analisa spasial dengan peta.

SIG mempunyai kekuatan untuk membuat suatu peta, mengumpulkan informasi, menggambarkan suatu skenario, dan memecahkan suatu permasalahan yang kompleks, selain itu SIG juga mampu mengembangkan suatu solusi efektif terhadap objek geografi (fisik, budaya atau ekonomi alamiah) yang belum pernah ada sebelumnya. Sebagai suatu aplikasi
SIG dapat digunakan oleh individu atau organisasi seperti perguruan tinggi, perusahaan, pemerintahan, militer, bisnis, dan masih banyak lagi bidang lainnya.

Dari definisi di atas dapat disimpulkan bahwa SIG merupakan suatu alat, metode, dan prosedur yang mempermudah dan mempercepat usaha untuk menemukan dan memahami persamaan-persamaan dan perbedaan-perbedaan yang ada dalam ruang muka bumi. Keyword yang menjadi titik tolak perhatian SIG adalah lokasi geografis dan analisis spasial yang secara bersama-sama merupakan dasar penting dalam suatu sistem informasi keruangan.

Dalam SIG terdapat 3 dimensi/aspek/label, yaitu (bukukomputer. blogspot.com, 2007) :

a. Dimensi keruangan (spatial dimentions), yang menunjuk pada sifat ruang atau lokasi geografi di permukaan bumi.

b. Dimensi waktu (temporal dimentions), saat dalam suatu waktu / periode tertentu

c. Dimensi tematik, dimensi ini menerangkan apa yang diukur seperti bentuk, kedalaman, variabel. Kadang-kadang dimensi tematik ini disebut sebagai dimensi topikal atau dimensi karakteristik.

\section{Peta Topografi, Tematik, dan Dasar}

Jenis peta secara garis besar hanya ada dua yaitu peta topografi dan peta tematik. Peta topografi bersifat umum sehingga penyajiannya tidak menonjolkan satu aspek, sedangkan peta tematik penyajiannya dengan menonjolkan tema/topik sesuai dengan judul peta itu sendiri. Misalnya penyajian jenis jalan di peta topografi tidak menonjol antara satu ruas jalan dengan ruas jalan yang lain yang jenis jalannya berbeda, ruas jalan tersebut di peta topografi juga tidak boleh menonjol dibandingkan dengan pola aliran sungai. Tetapi di peta tematik ruas jalan yang statusnya berbeda akan tampak ditonjolkan dibandingkan dengan aspek lainnya.

Peta dasar merupakan dasar untuk memetakan informasi spasial sehingga informasiinformasi tersebut baik secara relatif maupun absolut menempati lokasi geografis yang benar. Peta dasar dapat berupa peta topografi secara lengkap atau sudah dikurangi informasinya agar tidak rancu dengan informasi tematiknya. Peta topografi yang sering digunakan sebagai peta dasar dalam pembuatan peta tematik sudah standar, baik dalam ukuran kertasnya, luas liputannya, maupun penyajian aspek kartografi lainnya. Peta tematik itu sendiri merupakan suatu 
peta yang menyajikan informasi khusus yang mempunyai satu tema. Peta tematik banyak sekali macamnya, seperti peta sistem lahan, peta penggunaan lahan, peta tanah, peta geologi, peta penyebaran jumlah penduduk dan sebagainya.

\section{Ruang Terbuka Hijau Kawasan Perkotaan}

Ruang terbuka adalah ruang-ruang dalam kota atau wilayah yang lebih luas baik dalam bentuk area/kawasan maupun dalam bentuk area memanjang/jalur di mana dalam penggunaannya lebih bersifat terbuka yang pada dasarnya tanpa bangunan.

Ruang Terbuka Hijau Kawasan Perkotaan yang selanjutnya disingkat RTHKP adalah bagian dari ruang terbuka suatu kawasan perkotaan yang diisi oleh tumbuhan dan tanaman guna mendukung manfaat ekologi, social, budaya, ekonomi dan estetika. Dimana kawasan perkotaan merupakan kawasan yang mempunyai kegiatan utama bukan pertanian dengan susunan fungsi kawasan sebagai tempat pemukiman perkotaan, pemusatan dan distribusi pelayanan jasa pemerintah, pelayanan sosial, dan kegiatan ekonomi.

Tujuan dari penataan RTHKP antara lain sebagai berikut :

a. Menjaga keserasian dan keseimbangan ekosistem lingkungan perkotaan.

b. Mewujudkan keseimbangan antara lingkungan alam dan lingkungan buatan diperkotaan.

c. Meningkatkan kualitas lingkungan perkotaan yang sehat, indah, bersih dan nyaman.

Fungsi RTHKP adalah:
a. Pengamanan keberadaan kawasan lindung perkotaan.
b. Pengendali pencemaran dan kerusakan tanah, air dan udara.
c. Sarana estetika kota.

Manfaat RTHKP adalah:
a. Sarana untuk mencerminkan identitas daerah.
b. Sarana penelitian, pendidikan dan penyuluhan.
c. Meningkatkan nilai ekonomi lahan perkotaan.
d. Memperbaiki iklim mikro

Metode Penelitian Yang dilakukan dalam pembuatan Penelitian ini, penulis menggunakan beberapa metode penelitian yaitu :

a. Metode Pengamatan (Observation)

Metode ini dilakukan dengan melakukan peninjauan dan pengamatan di lingkungan kerja untuk mendapatkan keterangan yang berguna dalam penyusunan laporan.

b. Metode Wawancara (Interview)

Metode ini dilakukan dengan cara mengumpulkan informasi / keterangan / jawaban yang tepat dari hal yang kurang jelas dengan mengadakan tanya jawab secara langsung dengan pihak-pihak yang bersangkutan.

c. Metode Pustaka (Reference)

Metode ini dilakukan dengan cara membaca, mengamati dan memahami beberapa sumber tertulis seperti buku, katalog dan laporanlaporan sehingga diperoleh informasi yang dapat membantu proses penyusunan laporan ini, sumber tertulis yang dimaksud dapat dilihat di daftar pustaka.

d. Metode Diskusi

Metode yang dilakukan dengan cara mencoba memecahkan suatu masalah dengan saling bertukar pikiran antar sesama mahasiswa maupun dosen pembimbing tentang suatu permasalahan mengenai pembuatan penelitian sehingga didapat suatu kesimpulan yang tepat

\section{Model Proses Perangkat Lunak}

Model proses perangkat lunak yang penulis pilih untuk membuat aplikasi SIG ini adalah model waterfall.

Adapun alasan penulis memilih model ini karena model ini bersifat sistematik dan berurutan dalam membangun software. Dalam membangun aplikasi ini sendiri bersifat kaku, dimana kebutuhan harus dikumpulkan secara lengkap sehingga perubahan bisa ditekan sekecil mungkin. Keuntungan dari model waterfall adalah terstruktur dan dokumen yang dihasilkan dapat di spesifikasikan secara jelas dan mendetail.

\section{METODOLOGI PENELITIAN}




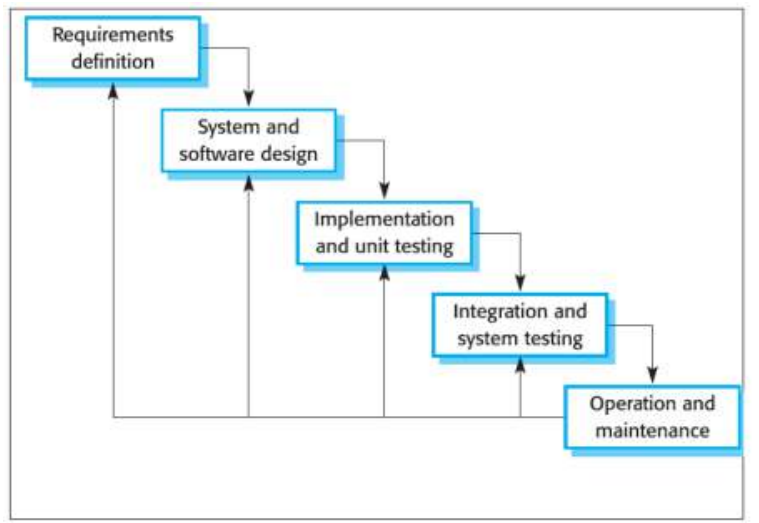

gambar 1.Fase-fase dalam model waterfall

- Requirements analysis and definition : Mengumpulkan kebutuhan secara lengkap kemudian kemudian dianalisis dan didefinisikan kebutuhan yang harus dipenuhi oleh program yang akan dibangun. Fase ini harus dikerjakan secara lengkap untuk bisa menghasilkan desain yang lengkap.

- System and software design : Desain dikerjakan setelah kebutuhan selesai dikumpulkan secara lengkap.

- Implementation and unit testing : desain program diterjemahkan ke dalam kode-kode dengan menggunakan bahasa pemrograman yang sudah ditentukan. Program yang dibangun langsung diuji baik secara unit.

\section{HASIL DAN PEMBAHASAN}

Program aplikasi ini terdiri dari beberapa form. Form pertama kali yang muncul ketika program dijalankan/di-run adalah Mapviewform, dimana pada form ini user dapat melihat peta kota Banjarmasin.

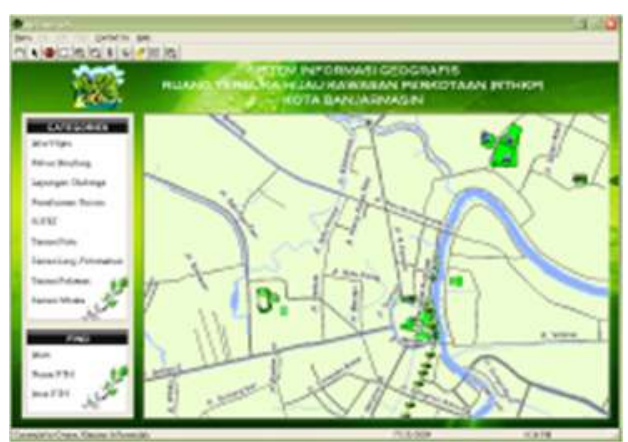

Gambar 2 Tampilan awal program

Jika user/pengguna ingin melakukan pengeditan terhadap informasi pada peta yang bersangkutan maka user tersebut harus login sebagai administrator. Dengan cara menginputkan username dan password.

\section{Login}

User pada program aplikasi ini dibedakan menjadi dua yaitu admin dan user biasa. Jika kita sebagai user biasa maka tidak harus login untuk menggunakan program aplikasi ini, karena user biasa cuma bisa menggunakan aplikasi ini untuk melihat peta, lokasi, pencarian, dan mencetak/print tampilan peta, sedangkan untuk melakukan perubahan/pengeditan terhadap peta yang bersangkutan maka user yang berperan sebagai administrator harus login terlebih dahulu.
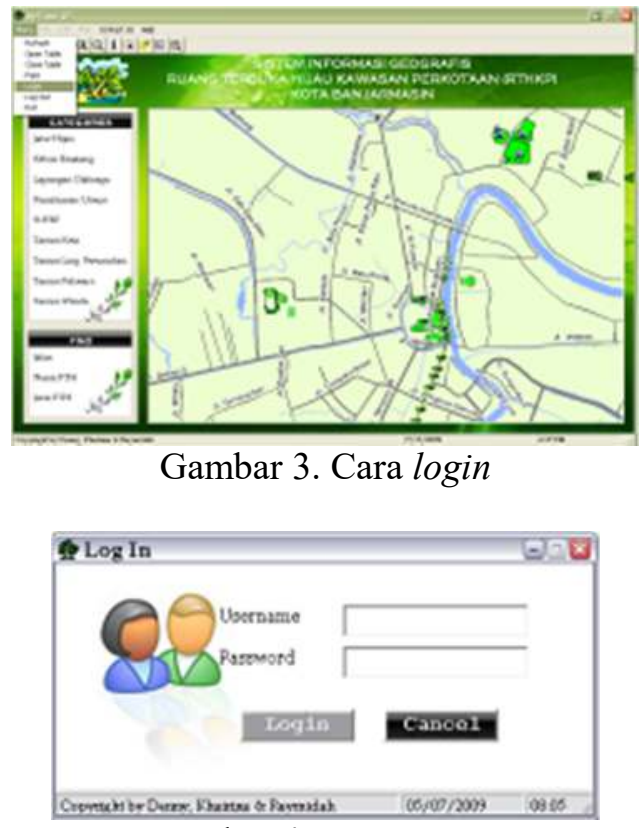

Gambar 4. Form Login

Adapun perbedaan tampilan setelah login sebagai admin adalah menu yang sebelumnya disabled seperti File, Edit, dan Map berubah menjadi enabled, selain itu caption formnya juga ada tambahan 'Login As Administrator'.

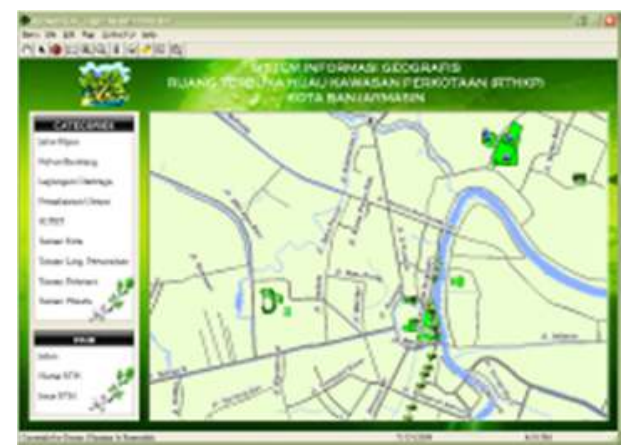

Gambar 5.

Tampilan setelah login sebagai admin

Jika proses login berhasil, maka admin dapat melakukan perubahan informasi yang diinginkan terhadap peta yang bersangkutan. 


\section{a. Editing}

User login sebagai admin, maka user tersebut bisa melakukan pengeditan yang akan diinginkan untuk diedit, jika sudah maka bisa dilakukan pengeditan yang diinginkan, seperti menambah simbol, garis, label, dan lain sebagainya.

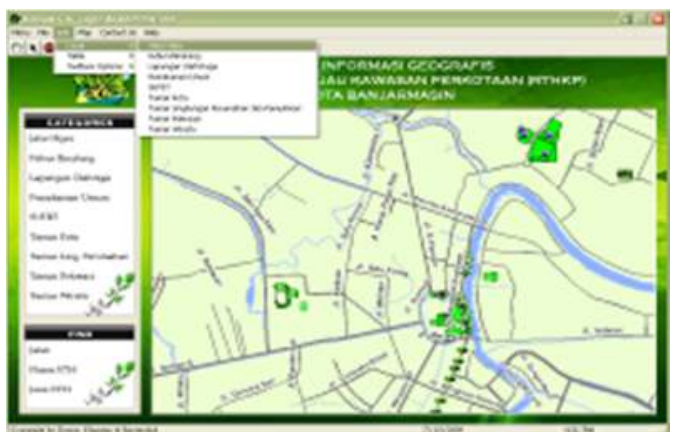

Gambar 6. Cara mengedit peta - menambah simbol

Misalkan layer yang dipilih adalah Jalur Hijau, setelah itu pilih salah satu fasilitas yang terdapat pada drawing, misalkan simbol. Jika sudah, klik di lokasi yang diinginkan. Maka simbol yang baru selesai ditambahkan.

\section{Pencarian}

Pencarian pada program aplikasi ini terbagi menjadi beberapa macam, yaitu : pencarian jalan, pencarian nama RTH, pencarian jenis RTH, dan pencarian berdasarkan kategori.

a. Pencarian Jalan

Pencarian jalan digunakan untuk memudahkan user mengetahui dimana letak jalan yang diinginkan, dengan cara menginputkan nama jalan yang ingin dicari.

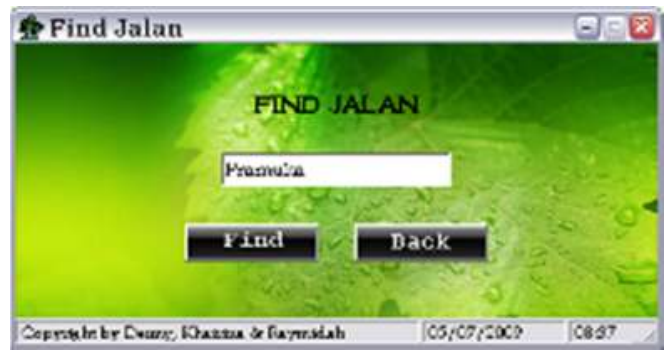

Gambar 7. Form Find Jalan

Setelah proses pencarian dilakukan, maka peta akan menandai lokasi dimana letak dari jalan yang dicari.

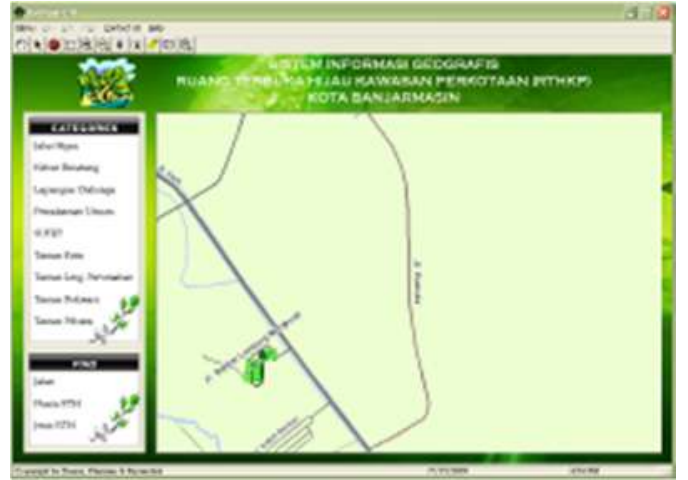

Gambar 8.

Tampilan peta setelah J1. Pramuka ditemukan

b. Pencarian Nama RTH

Pencarian nama RTH digunakan untuk memudahkan user mengetahui dimana lokasi dari nama RTH yang diinginkan, dengan cara menginputkan nama RTH yang ingin dicari.

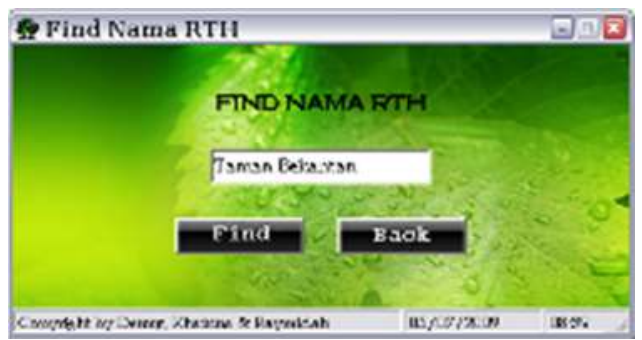

Gambar 9. Form Find Nama RTH

Setelah proses pencarian dilakukan, maka peta akan menandai lokasi dimana letak dari nama RTH yang dicari.

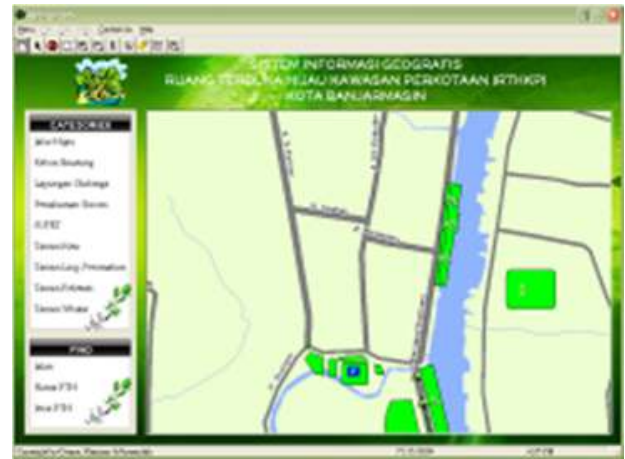

Gambar 10. Tampilan peta setelah Taman

Bekantan ditemukan

c. Pencarian Jenis RTH

Pencarian jenis RTH digunakan untuk memudahkan user mengetahui dimana lokasi dari jenis RTH yang diinginkan, dengan cara menginputkan jenis RTH yang ingin dicari, misal Lapangan Olahraga. 


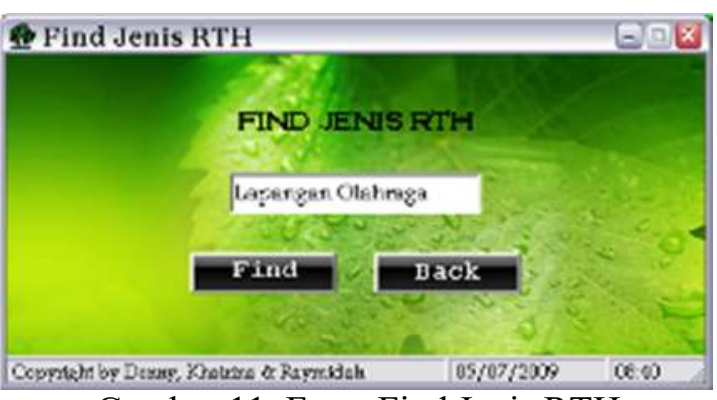

Gambar 11. Form Find Jenis RTH

Setelah proses pencarian dilakukan, maka peta akan menandai lokasi dimana letak dari jenis RTH yang dicari.

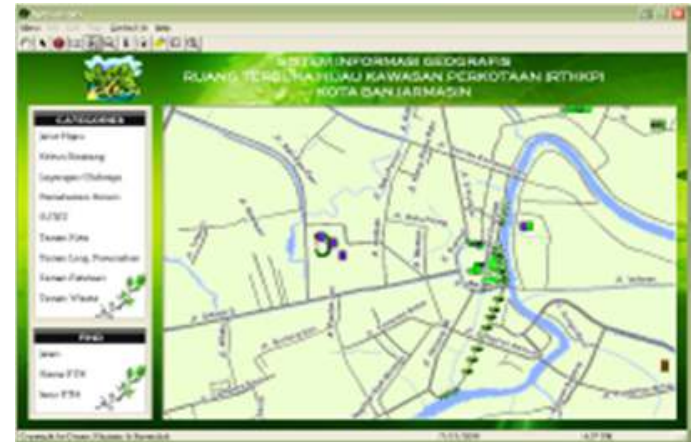

Gambar 12. Tampilan peta setelah Lapangan Olahraga ditemukan

d. Pencarian Berdasarkan Kategori

Pencarian berdasarkan kategori ini digunakan untuk memudahkan user, kategori apa saja yang ingin dicari dan dimana letaknya. Misal kita ingin melakukan pencarian RTH dengan kategori Jalur Hijau, maka pada kotak dialog Categories pilih Jalur Hijau.

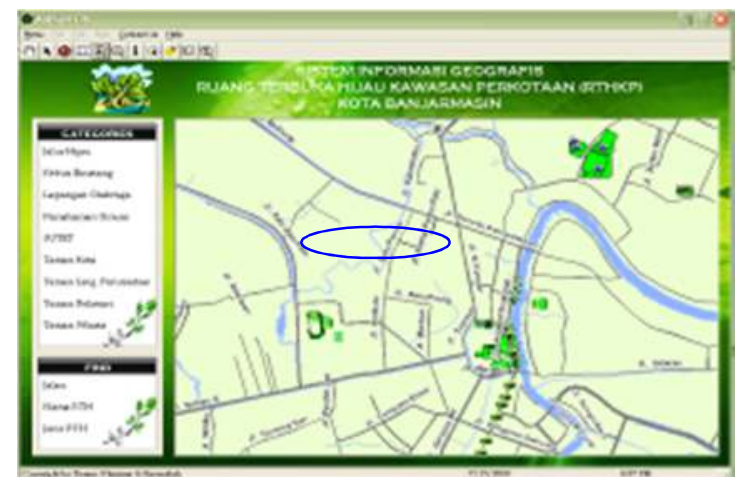

Gambar 13 Memilih kategori

Setelah proses pencarian kategori dilakukan, maka peta akan memunculkan layer yang isinya cuma kategori yang telah dipilih sebelumnya.

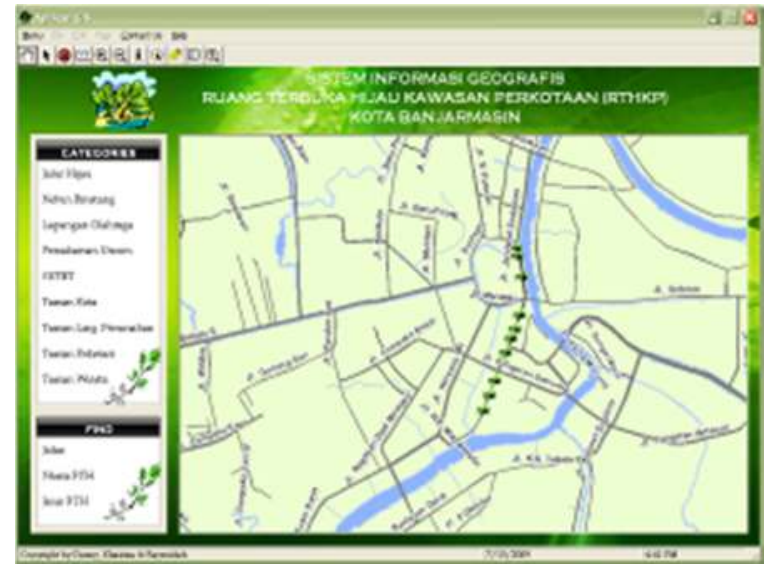

Gambar 14 Tampilan peta setelah kategori Jalur Hijau ditemukan

\section{b. Mencetak Peta}

Selain pencarian, program aplikasi ini juga menyediakan fasilitas untuk mencetak/print tampilan peta/lokasi yang diinginkan. Dan untuk menggunakan fasilitas ini, tidak harus user yang berperan sebagai administrator, user biasa juga bisa mencetak/print tampilan peta/lokasi yang diperlukan.

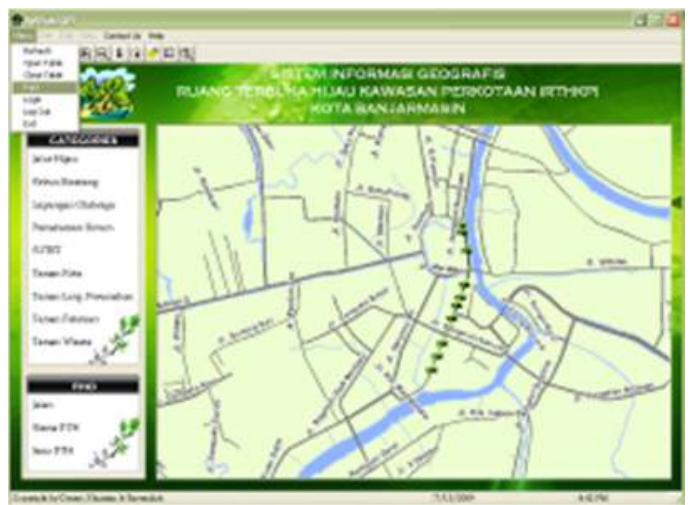

Gambar 15 Cara mencetak peta (Print)

Setelah itu atur properti sesuai keinginan, jika sudah tampilan peta siap dicetak.

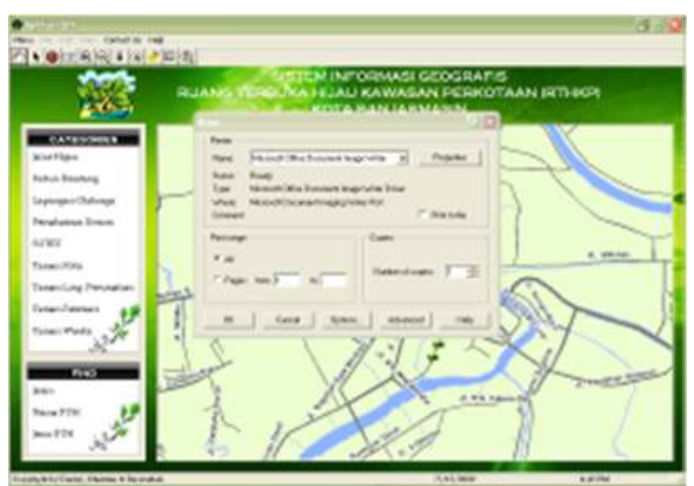

Gambar 16 Setting Print 


\section{c. Pengujian}

Dalam pembuatan aplikasi ini, pengujian dilakukan setiap form, setelah selesai membuat satu form pengujian dilakukan, begitu seterusnya sampai semua form selesai dibuat. Setelah itu dilakukan pengujian lagi secara keseluruhan program untuk mengetahui apakah aplikasi ini sudah sesuai dengan yang diinginkan atau belum.

\section{KESIMPULAN}

Dengan teknologi Program Sistem Informasi Geografis Sebagai Pendukung Penataan Ruang Terbuka Hijau Kawasan Perkotaan (RTHKP) Kota Banjarmasin, bisa memberikan informasi lahan-lahan mana saja yang sesuai untuk RTHKP secara cepat, tepat dan sesuai dengan keadaan sesungguhnya dan juga sebagai sarana bantu dalam mengambil suatu keputusan dalam perencanaan dan penataan RTHKP kota Banjarmasin

\section{DAFTAR PUSTAKA}

Pardosi, Mico. 2005. Microsoft Visual Basic 6.0 : Untuk Windows 98, 2000, NT, XP. Surabaya : Dua Selaras.

Prahasta, Eddy. 2005. Sistem Informasi Geografis: Aplikasi Pemograman Mapinfo. Bandung : Informatika.

Prahasta, Eddy. 2006. Sistem Informasi Geografis: Belajar dan Memahami Mapinfo. Bandung : Informatika.

Ramadhan, Arief. 2004. 36 Jam Belajar Komputer: Visual Basic 6.0. Bogor : Elex Media Komputindo

Triangga, Giri. 2007. "Konsep Dasar Sistem Informasi Geografi (SIG)". http://bukukomputer.blogspot.com/2007/0 3/konsep-dasar-sistem-informasigeografis.html. 